\title{
Produksi ikan asin dengan menerapkan teknologi pengeringan berbasis energi biomassa yang ramah lingkungan untuk meningkatkan ekonomi masyarakat di Desa Buluh Cina, Kecamatan Siak Hulu, Kampar
}

\author{
Krisman*, Erwin, Hamdi, dan T. Emrinaldi \\ Universitas Riau \\ *juandi_m@rocketmail.com
}

\begin{abstract}
Abstrak. Potensi sektor usaha ekonomi masyarakat di desa Buluh Cina Kecamatan Siak Hulu, Kampar yang memiliki potensi perikanan. Sistim pengolahan ikan menjadi produk ikan asin dilakukan melalui pengawetan ikan dengan metode pengeringan telah lama dipraktekkan oleh pengusaha pengawet ikan. Secara khusus, kegiatan pengeringan ikan telah sejak lama menjadi mata pencaharian bagi komunitas pengolahan ikan asin yang ada di desa Buluh Cina Kecamatan Siak Hulu, Kampar. Namun, pada umumnya, proses pengawetan ikan melalui metode pengeringan dengan hanya mengandalkan sinar matahari belum optimal. Proses pengeringan ikan di desa Buluh Cina Kecamatan Siak Hulu, Kampar masih dilakukan secara tradisonal, yaitu dijemur di bawah sinar matahari. Proses ini memakan waktu yang cukup lama, dibutuhkan waktu dalam pengeringan ikan 2 sampai 4 hari dan itu pun tergantung adanya sinar matahari. Tujuan Kegiatan ini adalah menerapkan teknologi pengering berbasis biomassa untuk produksi ikan asin. Metode yang dilakukan adalah dengan membuat alat pengering, tungku pembakaran biomass, ruang pengering (box). Hasil kegiatan pengabdian ini menunjukkan antusias yang tinggi dari masyarakat dimana produksi ikan asin dapat diperoleh hanya dalam waktu 1,5 jam dengan temperature dalam ruang pengering mencapai $35 \mathrm{~s} / \mathrm{d} 40$ derajat Celsius.
\end{abstract}

Kata kunci: biomassa; ikan asin; pengeringan; teknologi

\begin{abstract}
The potential of the economic sector of the community in the village of Buluh China, Siak Hulu Subdistrict, Kampar which has potential fisheries. The system of processing fish into salted fish products carried out through fish preservation by drying methods has long been practiced by fish preservative entrepreneurs. In particular, fish drying activities have long been a livelihood for salted fish processing communities in Buluh China village, Siak Hulu SubDistrict, Kampar. However, in general, the process of preserving fish through drying methods by relying solely on sunlight is not optimal. The process of drying fish in Buluh China village, Siak Hulu Subdistrict, Kampar is still traditionally carried out, which is dried in the sun. This process takes a long time, it takes time in drying fish 2 to 4 days and that too depends on the sun. The purpose of this activity is to apply biomass-based drying technology for salted fish production. The method used is to make a dryer, biomass burning furnace, drying room (box). The results of this service show high enthusiasm from the community where salted fish production can be obtained in just 1.5 hours with temperatures in the drying chamber reaching 35 to 40 degrees Celsius.
\end{abstract}

Keywords: salted fish; biomass; drying; technology

To cite this article: Krisman, Erwin, Hamdi, \& T. Emrinaldi. 2019. Produksi ikan asin dengan menerapkan teknologi pengeringan berbasis energi biomassa yang ramah lingkungan untuk meningkatkan ekonomi masyarakat di Desa Buluh Cina, Kecamatan Siak Hulu, Kampar. Unri Conference Series: Community Engagement 1: $333-340$ https://doi.org/10.31258/unricsce.1.333-340

(C) 2019 Authors

Peer-review under responsibility of the organizing committee of Seminar Nasional Pemberdayaan Masyarakat 2019 


\section{PENDAHULUAN}

Desa Buluh Cina merupakan salah satu desa yang berada di Kecamatan Siak Hulu, Kabupaten Kampar, Provinsi Riau. Desa ini memiliki luas wilayah sebesar 6.400 Ha. Desa Buluh Cina berada di area yang dikelilingi oleh hutan dan perkebunan kelapa sawit dengan jenis tanah kuning berpasir. Jarak dari Kota Pekanbaru ke Desa Buluh Cina, Kecamatan Siak Hulu lebih kurang 30 km.

Desa Buluh Cina menjadi desa yang paling menarik dibandingkan desa - desa tetangganya. Ditambah Desa Buluh Cina merupakan desa wisata. Hal ini dapat dilihat dari keberadaan fasilitas publik yang tersedia di desa ini. Dengan memanfaatkan dana desa bantuan pemerintah pusat, pertumbuhan penggunaan lahan untuk fasilitas publik seperti sarana kesehatan, sarana pendidikan dan olahraga di Desa Buluh Cina berkembang cukup pesat. Selain itu, penggunaan lahan untuk perkebunan kelapa sawit di Desa Buluh Cina juga berkembang cukup pesat. Potensi sektor usaha ekonomi masyarakat yang memiliki potensi perikanan yang sangat potensial di Kabupaten Kampar. Potensi sektor perikanan tawar yang sangat besar permasalahan yang ditemui pada kelompok usaha ikan asin patin yang ada adalah Sistim pengolahan ikan baung.

Sistim pengolahan ikan patin menjadi produk ikan asin patin dilakukan melalui pengawetan ikan patin dengan metode pengeringan secara tradisonal, yaitu dijemur di bawah sinar matahari. Proses ini memakan waktu yang cukup lama, dibutuhkan waktu dalam pengeringan ikan 3 sampai 4 hari dan itu pun tergantung adanya sinar rmatahari.Permasalahan lain adalah kualitas hasil pengeringan tradisional masih kurang baik, yaitu sering dihinggapi oleh lalat. Teknologi pengeringan berbasis energi biomassa untuk produksi ikan asin dan dijadikan sebagai sumber mata pencarian. Melalui Program ini kualitas ikan asin meningkat.

Desa Buluh cina adalah merupakan daerah wilayah di kecamatan Siak Hulu Kabupaten Kampar ini yang menurut beberapa tokoh masyarakat desa Buluhcina dikenal karena pada zaman dahulu adanya sebuah bamboo tempat tambatan perahu yang ditancapkan ditanah pinggiran sungai. Nama bambu tersebut adalah Bambu Cina dalam bahasa daerahnya Bambu adalah Buluh jadi menjadi sebutan tempat/daerah tersebut dengan Buluhcina. Dengan adat istiadat yang turun temurun diwarisi oleh masyarakat adat setempat.

Disamping jarak tempuh yang cukup dekat dari Pusat Kota Provinsi Riau, kebanyakan penduduk telah memiliki sarana kendaraan roda dua serta ditunjang dengan sarana jalan dengan keadaan yang terbilang bagus. $\mathrm{Hal}$ ini tentunya sangat mendukung perkembangan perekonomian dan pelaksanaan Desa Buluhcina. Wilayah Desa Buluhcina termasuk dataran rendah, yang sebagaian besar terdiri dari tanah perkebunan dengan kesuburan tanah cukup tinggi, sehingga hasil perkebunan sangat mendukung kesejahteraan masyarakat.

\section{MASALAH}

Berdasarkan identifikasi diatas maka permasalahan yang ada di Desa Buluh Cina Kecamatan Siak Hulu Kabupaten Kampar, yaitu:

1. Masih menggunakan Pengeringan ikan secara tradisional, sehingga target kegiatan ini akan menghasilkan teknologi pengeringan ikan asin berbasis biomassa.

2. Waktu pengeringan yang lama 3-4 hari, sehingga target kegiatan ini akan menghasilkan teknologi pengeringan yang efesien.

3. Masyarakat belum mengenal Teknologi pengeringan ikan, sehingga target kegiatan ini akan memberikan sosialisasi dan transfer alih teknologi.

\section{METODE}

\section{Lokasi Kegiatan Pengabdian}

Lokasi Kegiatan pengabdian ini berada di Desa Buluh Cina, Kecamatan Siak Hulu, Kabupaten Kampar Provinsi Riau.

\section{Waktu Kegiatan}

Kegiatan ini bersamaan dengan KUKERTA terintegrasi dengan durasi kegiatan sebanyak 14 kali pertemuan mencakup kedalam semua kegiatan mahasiswa yang KUKERTA di Desa Buluh Cina, Kecamatan Siak Hulu, Kabupaten Kampar.

\section{Alat dan Bahan}

Alat dan bahan yang digunakan dalam pengabdian ini ditunjukkan dalam Tabel 1 sebagai berikut: 
Tabel 1. Alat dan bahan

\begin{tabular}{cll}
\hline No. & Alat dan Bahan & Fungsi \\
\hline 1 & Ikan & Sebagai bahan objek pengeringan \\
2 & Limbah tempurung kelapa & Sumber energi biomassa \\
3 & Seng & Sebagai atap alat pengering \\
4 & Triplek & Sebagai dinding alat pengering \\
5 & Busa & Sebagai isolator \\
6 & Kayu Broti & Sebagai penyangga alat pengering \\
7 & Paku & Sebagai perekat \\
8 & Drum & Sebagai ruang energi biomassa \\
9 & Kayu & Sebagai rak tempat kerupuk \\
10 & Cat hitam & Sebagai penyerap panas \\
11 & Plat seng & Sebagai dinding dan cerobong \\
12 & Stopwatch & Sebagai pengukur waktu pengeringan \\
13 & Timbangan digital & Sebagai pengukur massa kerupuk \\
14 & Timbangan analog & Sebagai timbangan massa tempurung \\
15 & Termometer & Sebagai pengukur temperatur ruang pengering \\
16 & Lem cap kambing & Sebagai perekat busa dengan triplek \\
\hline
\end{tabular}

\section{Rancang Bangun Alat Pengering Tipe Kabinet}

Ruang pengering tipe kabinet merupakan pengering yang ramahlingkungan. Adapun bentuk dari alat pengering dapat dilihat pada Gambar 1.

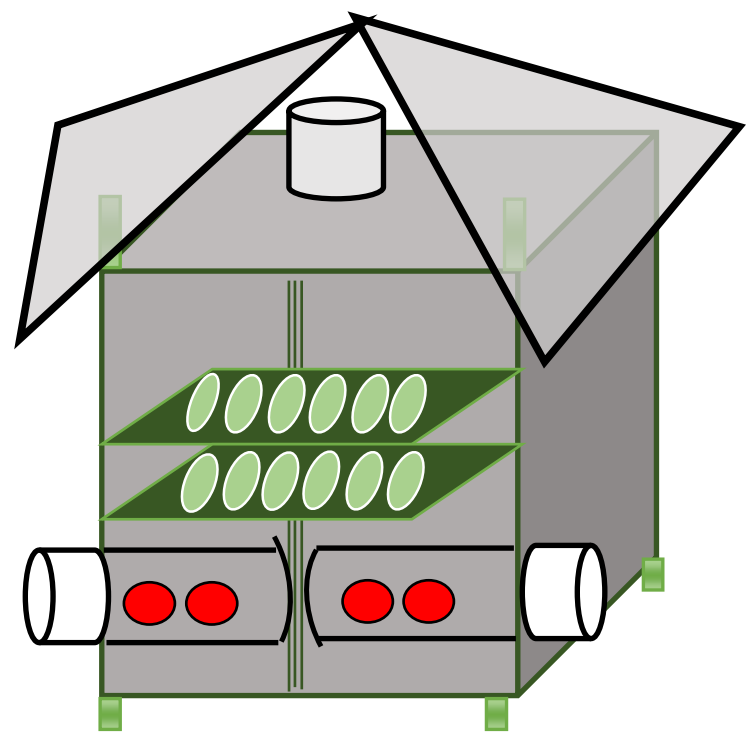

Gambar 1. Rancangan alat pengering tipe kabinet

Alat pengering tipe kabinet mempunyai spesifikasi sebagai berikut:

1. Luas ruangan pengering dengan ukuran $1,32 \mathrm{~m} \times 0,85 \mathrm{~m} \times 1,13 \mathrm{~m}$.

2. Atap memiliki ukuran panjang $1,54 \mathrm{~m}$, lebar $1,17 \mathrm{~m}$, dan tinggi $0,55 \mathrm{~m}$.

3. Memiliki cerobong dengan diameter $0,16 \mathrm{~m}$ dan tinggi $0,28 \mathrm{~m}$.

4. Terdapat 2 buah rak pengering yang masing-masing memiliki panjang $1,25 \mathrm{~m}$ dan lebar $0,71 \mathrm{~m}$ dan jarak antar rak $0,04 \mathrm{~m}$.

5. Terdapat 4 buah kaki penyangga pada alat pengering yang masing-masing memiliki tinggi $0,16 \mathrm{~m}$.

6. Ruang energi biomassa terdiri dari 2 buah drum berbentuk silinder yang masing-masing memiliki diameter $0,48 \mathrm{~m}$ dan panjang $0,55 \mathrm{~m}$. Drum ini diberi penyangga dengan tinggi $0,05 \mathrm{~m}$.

7. Dilengkapi dengan thermometer Celsius untuk skala penunjuk temperatur ruangan.

8. Bahan sumber energi biomassa dari limbah tempurung kelapa. 


\section{PEMBAHASAN}

\section{Luaran Utama Kegitan}

Biomassa dapat digunakan sebagai sumber energy (Asnawi. 2002). Teknologi diperlukan untuk dapat memanfaatkan energy guna keperluan manusia (Irawan B. 2001. Luaran utama kegiatan pengabdian ini adalah menghaasilkan teknologi pengeringan ikan asin berbasis biomassa, seperti ditunjukkan pada Gambar 2 .

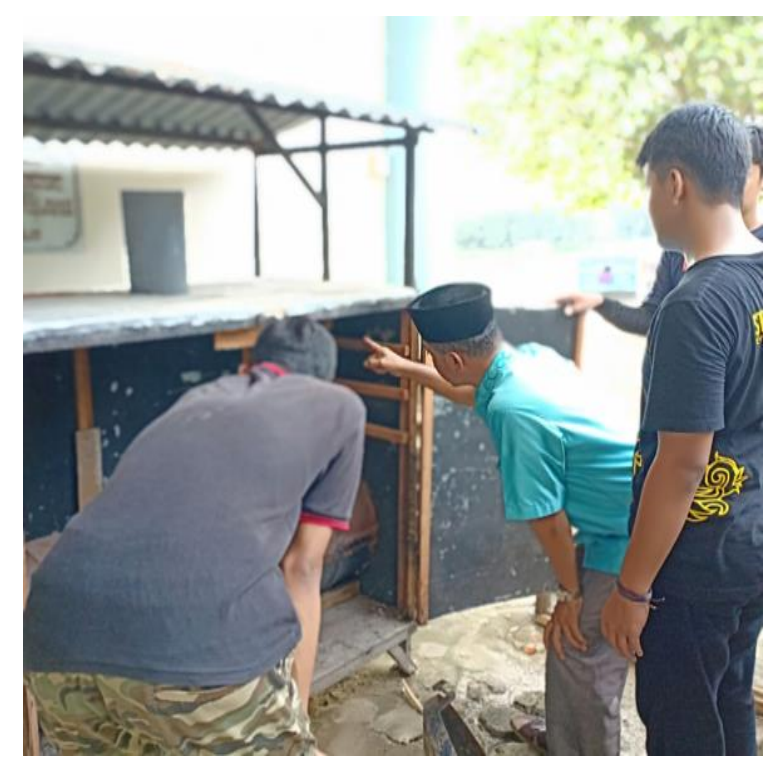

Gambar 2. Luaran utama kegiatan pengabdian

Gambar 2 menunjukkan luaran utama kegiatan pengabdian, yaitu berupa alat teknologi pengering ikan asin berbasis energy biomassa. Tampak pada Gambar 2, tim Kukerta terintegrasi telah melakukan sosialisasi teknologi pengering berbasis biomassa. Alat teknologi ini memiliki efesiensi kerja yang baik, hanya dalam tempo waktu 60 menit telah berhasil menghasilkan ikan asin yang berkualitas baik.

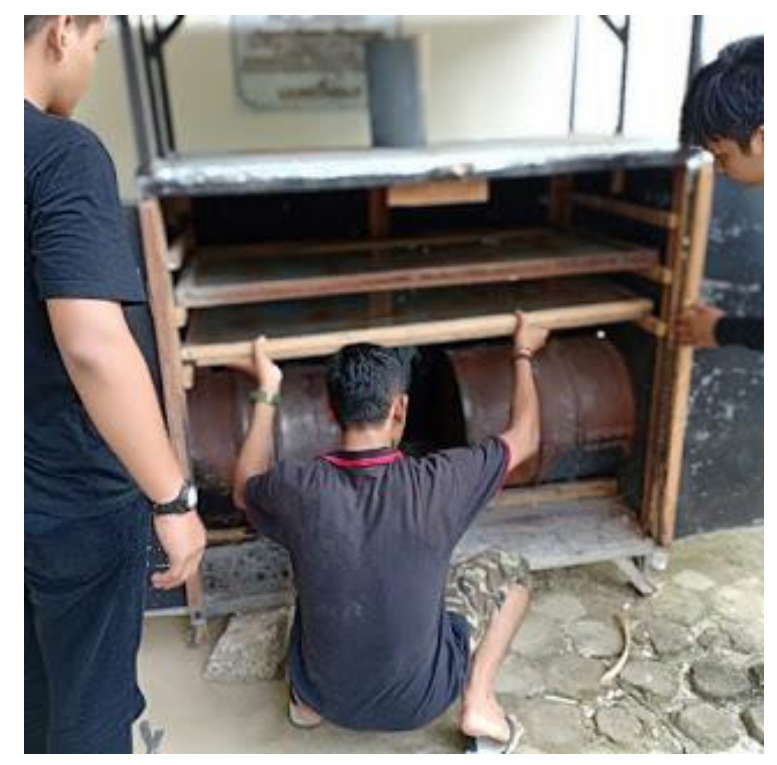

Gambar 3. Masyarakat sedang melakukan praktek teknologi pengeringan biomassa

\section{Keunggulan dan kelemahan kegiatan}

Adapun keunggulan kegiatan pengabdian ini terletak pada efesiensi waktu dan peningkatan manajemen produksi. Secara efesiensi waktu masyarakat hanya memerlukan waktu 60 menit untuk mengeringkan ikan asin, dan peningkatan manajemen produksi ditandai dengan tidak perlu lagi masyarakat melakukan 
pengawasan, artinya terhindar dari gangguan hewan ternak, anak-anak dan hujan, tentu hal ini akan dapat meningkatkan produksi dari $5 \mathrm{~kg}$ dapat menjadi $15 \mathrm{~kg}$ bahkan lebih, tergantuan pada kesediaan bahan baku yang akan diolah (Gambar 3). Hasil kegiatan pengabdian ini menunjukkan antusias yang tinggi dari masyarakat dimana produksi ikan asin dapat diperoleh hanya dalam waktu 1,5 jam dengan temperature dalam ruang pengering mencapai $35 \mathrm{~s} / \mathrm{d} 40$ derajat Celsius.

Gambar 3 menunjukkan masyarakat sedang melakukan praktek penggunaan alat teknologi pengering berbasis biomassa, dimana ikan yang akan dikeringkan di letakkan dalam rak-rak pengering sebagaimana terlihat dalam Gambar 3.

\section{Tingkat kesulitan pelaksanaan kegiatan}

Tingkat kesulitan pelaksanaan kegiatan pengabdian ini terlihat pada Respon masyarakat desa mengenai penyuluhan ini sangat bagus. Banyak masyarakat yang berbondong-bondong ingin mencoba alat dengan menggunakan ikan yang mereka punya. Selain itu juga, masyarakat juga kooperatif saat penyuluhan. Tidak hanya masyarakat yang berprofesi sebagai nelayan saja yang antusias, tetapi juga masyarakat desa Buluh cina juga tertarik dari penyuluhan ini (Gambar 4).

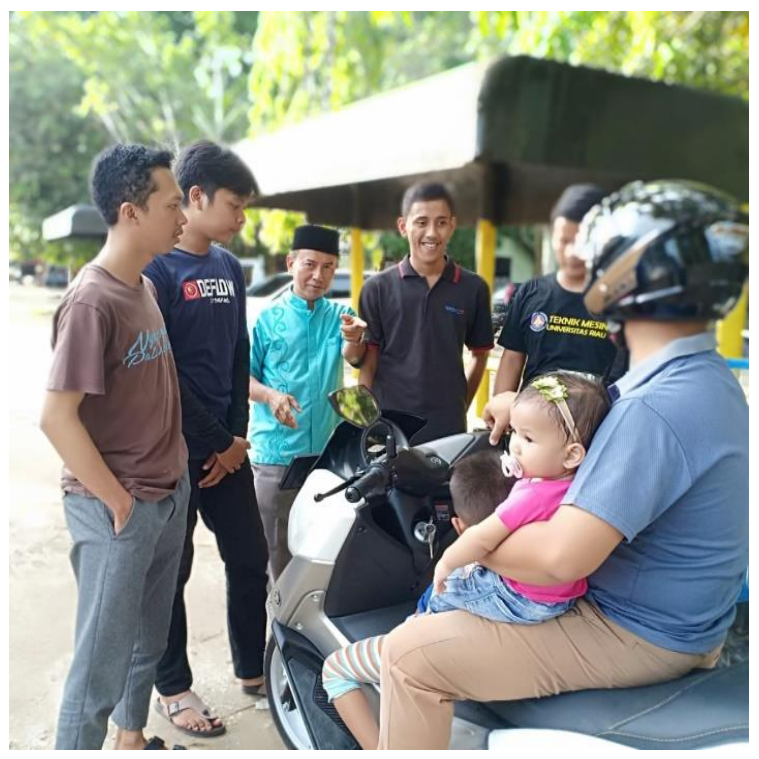

Gambar 4. Antusias warga terhadap kegiatan teknologi pengering berbasis biomassa

Gambar 4 menunjukkan antusias warga terhadap kegiatan pengabdian yang dilakukan, dimana warga yang sedang berjalanpun singgah dan bertanya tentang maksud kegiatan ini, karena tidak semua warga yang diundang dalam kegiatan ini, yang di undang hyanyalah warga yang berprofesi sebagai nelayan.

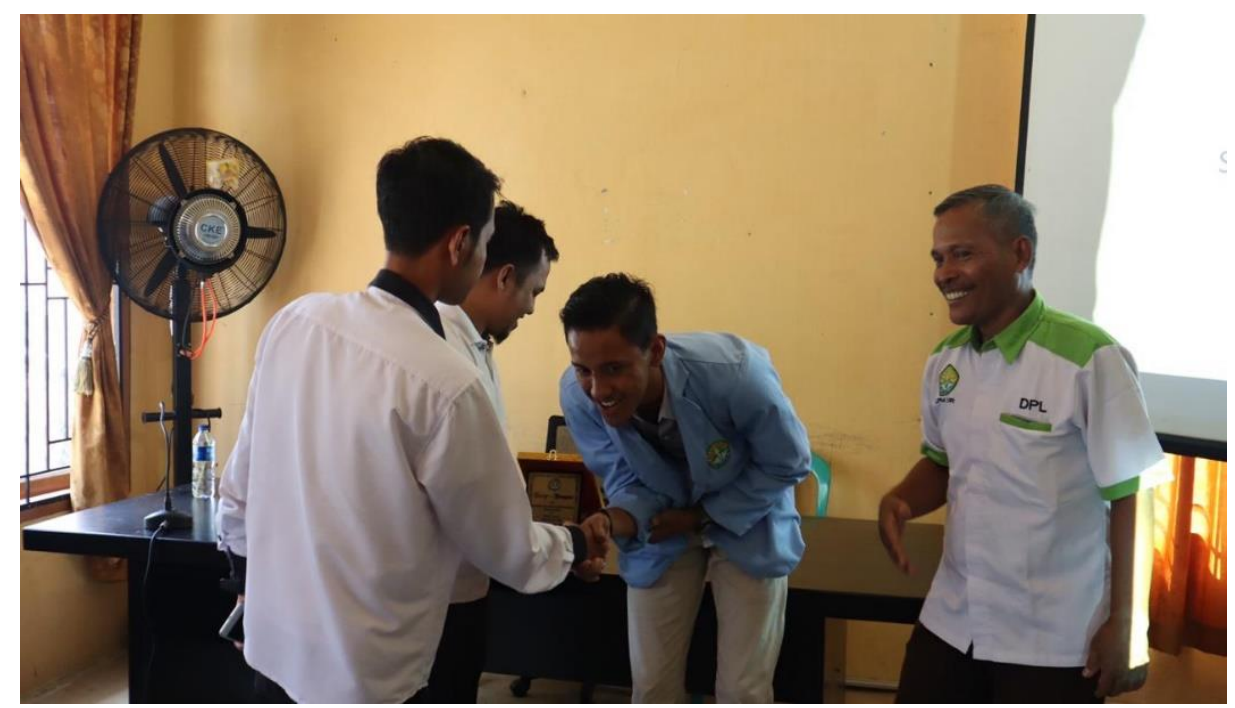

Gambar 5. Ungkapan antusias masyarakat terhadap kegiatan pengabdian 
Tingkat kepuasan warga juga ditandai dengan ucapan terima kasih yang disampaikan warga saat selesai kegiatan sosialisasi teknologi pengering ikan asin berbasis biomassa, seperti ditunjukkan dalam Gambar 5.

Kegiatan KUKERTA Terintegrasi UNRI 2019 melaksanakan kegiatan pengabdian kepada masyarakat Desa Buluh Cina dengan judul penelitian Produksi Ikan Asin dengan Menerapkan Teknologi Pengeringan Berbasis Energi Biomassa yang Ramah Lingkungan untuk Meningkatkan Ekonomi Masyarakat di Desa Buluh Cina Kecamatan Siak Hulu, Kampar.

Kegiatan pengabdian ini terintegrasi dengan KUKERTA mahasiswa UNRI tahun 2019 terdiri dari Muhammad Teguh dari Fakultas Teknik Jurusan Teknik Mesin. Sementara untuk anggota, berasal dari 5 Fakultas berbeda dengan jumlah anggota 9 orang. Yaitu Siti Fatimah dan Puji Nikmatul Husna dari Fakultas Matematika dan Ilmu Pengetahuan Alam jurusan Matematika, Yovie Suryani dari Fakultas Kedokteran, Fellycia Yulwanda dari Fakultas Keguruan dan Ilmu Pendidikan jurusan PAUD, Cika Ahdya Dewi Pratama dari Fakultas Ilmu Sosial dan Ilmu Politik jurusan Hubungan Internasional serta Athiyyah Rieke Hisaba,Afriadham Putra dan Iqbal Lazardo dari Fakultas Teknik jurusan Teknik Mesin.

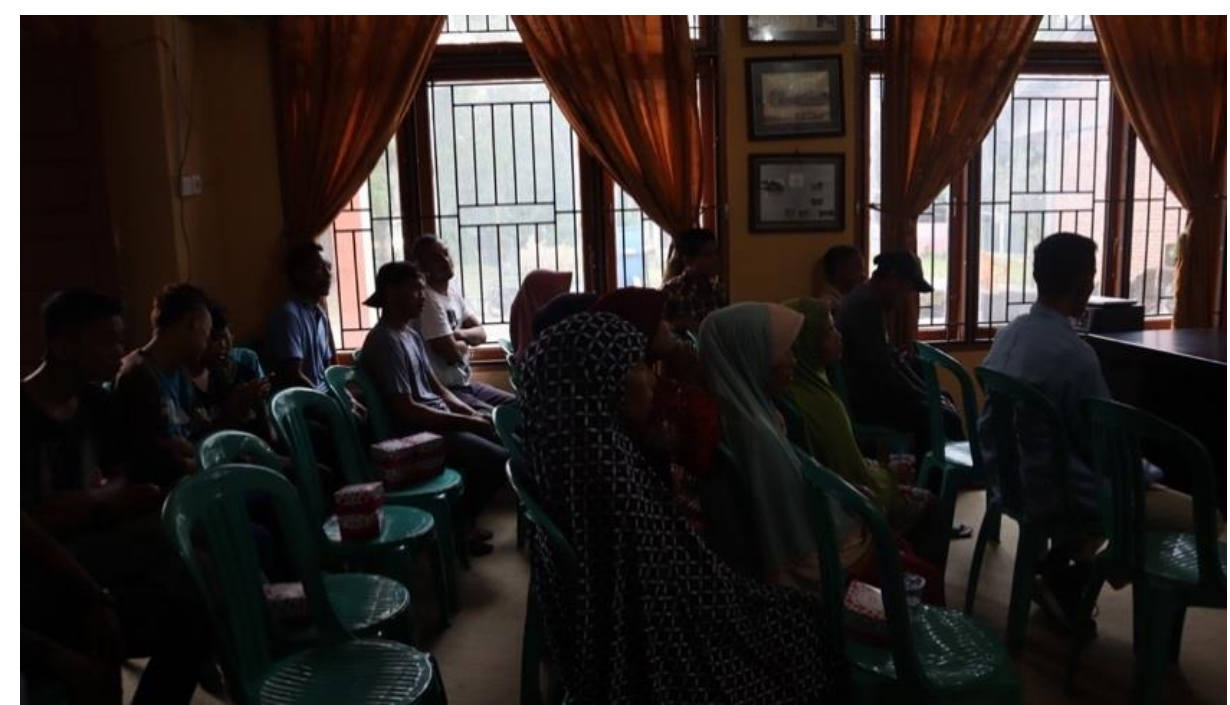

Gambar 6. Antusias masyarakat dalam sosialisasi teknologi biomassa

Kegiatan ini dilaksanakan di Desa Buluh Cina selama 2 minggu. Berdasarkan dari tema pengabdian, Kelompok Kukerta ini melaksanakan Penyuluhan Potensi Energi Biomassa yang Ramah Lingkungan, Penyuluhan Penerapan Energi Biomassa yang Ramah Lingkungan untuk Meningatkan Ekonomi Masyarakat, Penerapan Alat Teknologi Pengeringan Ikan Asin dan Penyuluhan Pemanfaatan Energi Biomassa yang Ramah Lingkungan untuk Pengeringan Ikan Asin. Masyarakat sangat antusias selama kegiatan (Gambar 6).

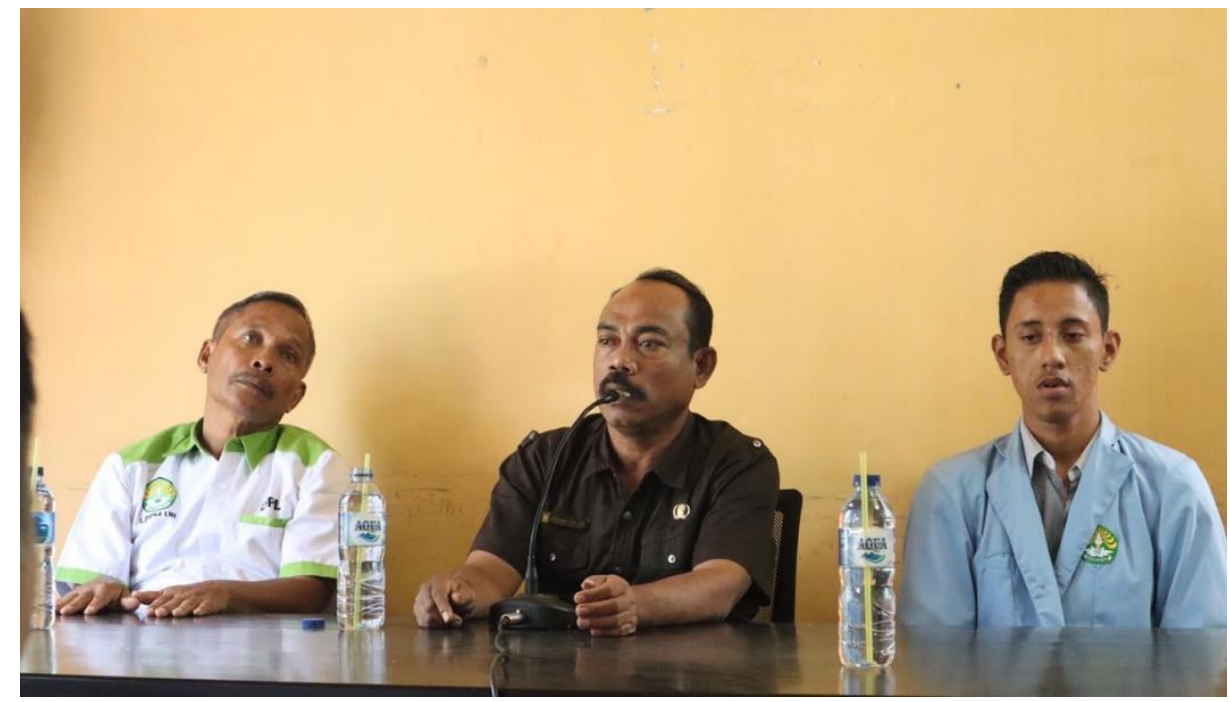

Gambar 7. Antusias terhadap kegiatan yang disampaikan kepala Desa Buluh Cina 
Antusias kegiatan ini ditandai juga dengan pernyataan Bapak Kepala Desa Buluh Cina, Bapak Muhammad Rais,SH mengatakan bahwasanya kegiatan ini mampu menjadi pusat peningkatan ekonomi masyarakat serta daya tarik pariwisata. Hal itu pun juga disetujui oleh Tokoh Masyarakat yang hadir. Selain menjadi ide ekonomi dan daya tarik pariwisata, teknologi pengeringan ikan asin berbasis energi biomassa ini juga sebagai pendukung dari sisi kesehatan (Gambar 7).

Teknologi dapat digunakan sebagai upaya untuk meningkatkan ekonomi masyarakat (Alma, 2000). Selain adanya penyuluhan tersebut, alat yang menjadi alat bantu pengeringan ikan asin ini diberikan kepada masyarakat Buluh Cina sebagai upaya peningkatan ekonomi Desa Buluh Cina melalui Dosen Pembimbing Lapangan kepada Kepala Desa Buluh Cina. Tampak pada Gambar 8, dimana Dosen Pembimbing KUKERTA (Drs. Krisman MSI) sedang menjawab pertanyaan dari masyarakat tentang efek positif dari kegiatan ini untuk meningkatkan pendapatan masyarakat di Desa Buluh Cina (Alma, 2000; Kornita, dkk, 2009).

\section{Diskusi tentang teknologi pengeringan ikan}

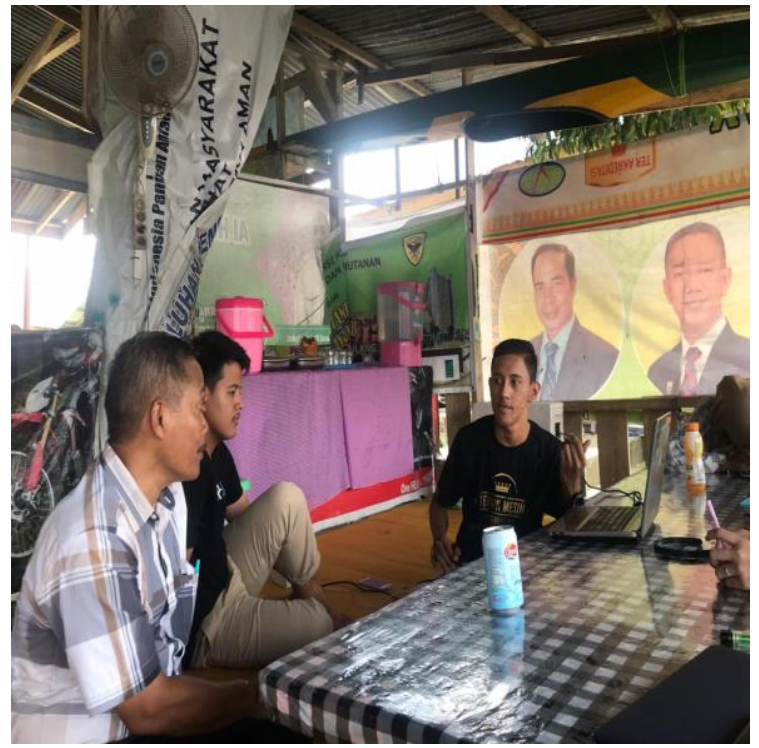

Gambar 8. Dosen pembimbing Kukerta memberikan penjelasan tentang efek positif dari teknologi ini.

Tanda keberhasilan dari pelaksanaan kegiatan pengabdian ini ditandai dengan foto bersama sebagai tanda bahwa kegiatan pengabdian ini telah sukses dilaksanakan di Desa Buluh Cina Kecamatan Siak Hulu, Kabupaten Kampar, seperti ditunjukkan dalam Gambar 9.

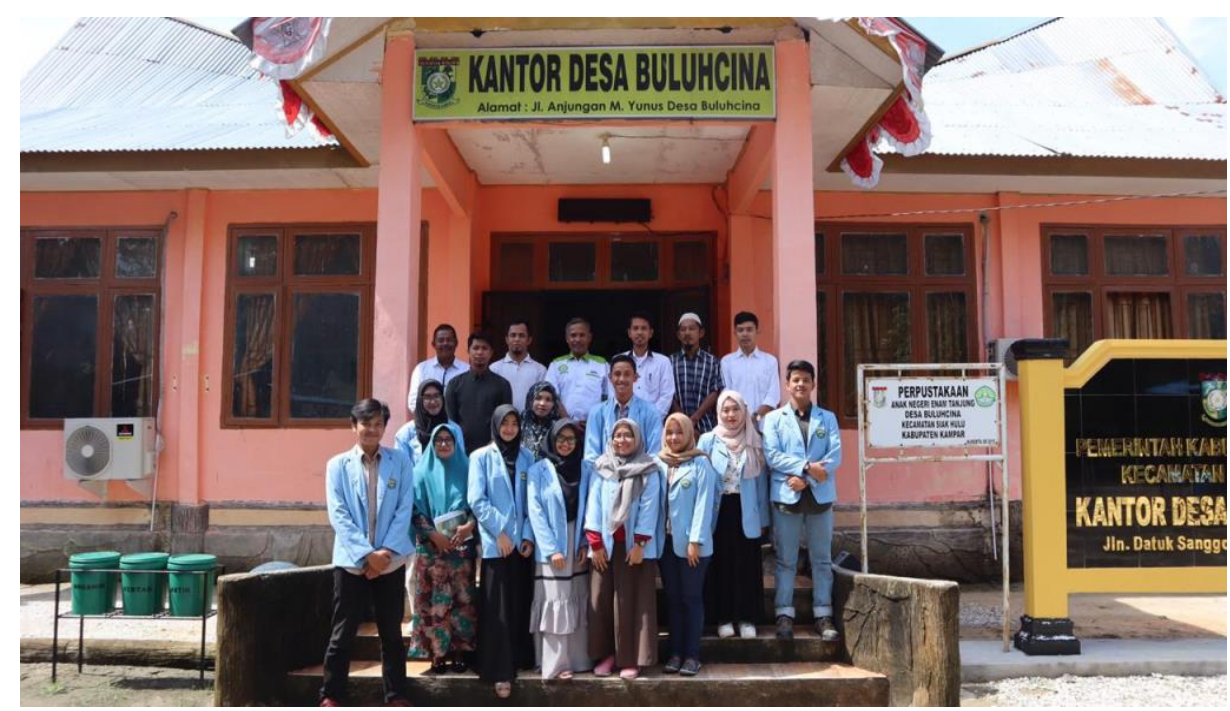

Gambar 9. Foto bersama seusai kegiatan pengabdian 


\section{KESIMPULAN}

Berdasarkan hasil pelaksanaan pengabdian pada masyarakat yang telah dilakukan serta analisa, maka dapat diambil kesimpulan yaitu telah berhasil diterapkan teknologi pengeringan berbasis biomassa untuk pengeringan ikan di Desa Buluh Cina Kecamatan Siak Hulu Kabupaten Kampar Provinsi Riau. Bahwa masyarakat sangat antusias dalam kegiatan tersebut, dimana produksi ikan asin dapat diperoleh hanya dalam waktu 1,5 jam dengan temperature dalam ruang pengering mencapai $35 \mathrm{~s} / \mathrm{d} 40$ derajat Celsius.

Rekomendasi yang diberikan agar masyarakat dapat secara konsisten menerapkan ilmu yang telah diajarkan yaitu penggunaan teknologi pengeringan berbasis biomassa untuk mengeringkan ikan.

\section{UCAPAN TERIMA KASIH}

Ucapan terima kasih kepada LPPM Universitas Riau yang telah memberi bantuan dana, dan ucapan terimaksih kepada mahasiswa Kukerta yang telah membantu dalam praktek lapangan bersama masyarakat.

\section{DAFTAR PUSTAKA}

Alma, B. 2000. Panduan Kuliah Kewirausahaan. Bandung: Alfabeta.

Asnawi. 2002. Aplikasi dan Penerapan Budidaya Kelapa Hibrida. Bandung: Armico.

Irawan, B. 2001. Penyerapan energy matahari dengan kolektor pelat datar. Jurnal Bisnis dan Teknologi 9(2): 314-318.

Kornita, S. E., Y. Yusuf, dan A. Mayes. 2009. Analisis perdagangan komoditas perikanan di Kecamatan Bantan Kabupaten Bengkalis. Jurnal Ekonomi 17(2). 